\title{
A EDUCAÇÃO NA RÚSSIA DOS SOVIETES: CONTRIBUIÇÕES DE VLADIMIR LENIN PARA REFLETIR “O FIM DA ESCOLA” NO CAPITALISMO
}

\author{
EDUCATION IN SOVIET RUSSIA: VLADIMIR LENIN CONTRIBUTIONS TO REFLECT \\ “THE END OF SCHOOL” IN CAPITALISM
}

\section{EDUCACIÓN EN RUSIA SOVIÉTICA: CONTRIBUCIONES DE VLADIMIR LENIN PARA REFLEXIONAR EL “FIN DE LA ESCUELA” EN EL CAPITALISMO}

DOI: http://dx.doi.org/10.9771/gmed.v12i2.37652

\author{
Vinícius Azevedo \\ Lucas André Teixeira
}

\begin{abstract}
Resumo: O presente artigo busca resgatar os princípios educacionais que guiaram Lenin na concepção das tarefas educacionais em três diferentes períodos: nos preparativos para a Revolução; no calor do momento; e no pós-1917 para a construção da sociedade socialista. Notou-se que, sob diferentes contextos, Lenin atribui propósitos distintos à educação e ao trabalho educativo. Por fim, o modelo de escola vigente no capitalismo é comparado com o modelo politécnico soviético, o que nos permitiu uma primeira aproximação ao entendimento de que o capitalismo, no seu atual estágio de desenvolvimento, caminha para "o fim da escola" que se universalizou na revolução burguesa.
\end{abstract}

Palavras-chave: Trabalho e Educação. Pedagogia Socialista. Revolução Russa.

Resumen: El presente artículo busca rescatar los principios educativos que guiaron a Lenin en el diseño de tareas educativas en tres períodos diferentes: en los preparativos para la Revolución; en el calor del momento; y después de 1917 para la construcción de la sociedade socialista. Se observó que, en diferentes contextos, Lenin asigna diferentes propósitos a la educación y al trabajo educativo. Finalmente, el modelo escolar vigente en el capitalismo se compara con el modelo politécnico soviético, que nos permitió un primer acercamiento a la comprensión de que el capitalismo, en su etapa actual de desarollo, se dirige hacia "el fin de la escuela" que se ha vuelto universal en la revolución burguesa.

Palabras clave: Trabajo y Educación. Pedagogía Socialista. Revolución Rusa.

Abstract: The present paper seeks to rescue the educational principles that guided Lenin in the conception of educational tasks in three different periods: in the preparations for the Revolution; on the spur of the moment; and post-1917 for the construction of socialist society. It was noted that under different contexts Lenin attributes different purposes to education and educational work. Lastly, the prevailing school model in capitalism is compared with the Soviet polytechnic model, which allowed us a first approach to the understanding that capitalism, in its current stage of development, is heading towards "the end of the school" that has become universal in the bourgeois revolution.

Keywords: Labour and Education. Socialist Pedagogy. Russian Revolution.

\section{Introdução}

Ao percorrer a trajetória de vida de Lenin, é possível encontrar aspectos que o conectam com as ideiais socialistas e a educação. Filho de Ilia Ulyanov, professor de matemática e física e Maria 
Alexandrovna Ulianova, pedagoga, Lenin perde aos 17 anos seu irmão, Alexandre, condenado à morte por enforcamento. Esse acontecimento exerceu profunda influência na juventude e formação política de Lenin. Alexandre era membro do Narodnaia volia (Vontade do Povo), grupo responsável pelo assassinato do czar Alexandre II, em $1^{\circ}$ de março 1881, e pela tentativa de assassinato do czar Alexandre III, no mesmo $1^{\circ}$ de março, dessa vez do ano de 1887.

No ambiente familiar de classe média intelectualizada, Lenin é educado com disciplina pessoal rígida e apreço ao conhecimento. Gradua-se em Direito pela Universidade de São Petersburgo tendo atuado como instrutor em círculos e universidades operárias (OYAMA, 2014, p. 107). Na década de 1890, conhece Nadejda Krupskaia em círculos clandestinos de discussão e difusão do marxismo e se casa em 1898. A influência de Krupskaia na vida de Lenin e no modelo de educação soviética a coloca como uma das grandes intelectuais responsáveis pela tarefa do estudo e aplicação de um modelo socialista de educação.

Lenin e Krupskaia participam da fundação do Partido Operário Social-Democrata Russo (POSDR) em 1898, a qual configuram-se como quadros políticos essenciais para a iminente Revolução. Em 1903, no II Congresso do POSDR, o partido se divide em duas alas: os bolcheviques - de Lenin - e os mencheviques. Sob o comando dos primeiros, a Revolução de Outubro de 1917 inaugura um importante período histórico de produção artística e científica fundamental para entender o século XX. Ao lado da experiência da Comuna de Paris de 1871, a Revolução Russa materializa o anseio dos trabalhadores em emancipar-se da exploração e competição capitalista e abre a possibilidade de construir sob novas bases o futuro da humanidade.

A tarefa de edificar o socialismo na Rússia sob as ruínas do czarismo demandava aos soviéticos o rompimento com as relações sociais capitalistas para dar existência a novas formas de produção e reprodução da vida, alinhadas com novas relações de trabalho e educação. Com esse intuito, inicia-se na Rússia pós-revolucionária formulações com base na concepção de educação politécnica presente em Karl Marx (1983, p. 80):

Por educação entendemos três coisas: 1. Educação intelectual; 2. Educação corporal, tal como a que se consegue com os exercícios de ginástica e militares; 3. Educação tecnológica, que recolhe os princípios gerais e de caráter científico de todo o processo de produção e, ao mesmo tempo, inicia as crianças e os adolescentes no manejo de ferramentas elementares dos diversos ramos industriais.

A amplitude do método revolucionário marxiano, a fim de compreender a concretude da economia na sociedade capitalista, trouxe contribuições categoriais e conceituais que foram apropriadas por autores que defendem uma pedagogia socialista, a exemplo do pensador e filósofo Dermeval Saviani, principal proponente da Pedagogia Histórico-Crítica.

Em contraponto aos princípios educativos que orientavam os socialistas na edificação da Rússia soviética, o modelo de educação apresentado no capitalismo apoia-se na contradição entre capital e trabalho, onde trabalhador e maquinário, capital variável e capital constante, respectivamente, são instrumentos de aquisição de lucro para o capitalista: 
[...] existe uma espécie de trabalho acumulado a que se chama capital; que este capital, graças às possibilidades que contém, multiplica por cem e por mil a produtividade do trabalho vivo e reivindica por isso uma certa compensação a que se chama lucro ou benefício. Percebemos todos nós que as coisas são, na realidade, assim: os lucros do trabalho morto, acumulado, formam uma massa cada vez maior, os capitais dos capitalistas tomam proporções cada vez mais colossais, enquanto o salário do trabalho vivo torna-se cada vez menor, e a massa dos operários que vive unicamente do salário, é cada vez maior e mais pobre. (MARX; ENGELS, 1961, p. 25).

A forma de exploração do trabalho que estrutura a sociedade capitalista configura-se como antinomia à integração politécnica presente nos escritos de Marx, uma vez que a integração entre trabalho intelectual e manual assume diferentes escopos no socialismo e no capitalismo, tal como nos modelos e concepções pedagógicas da e na educação.

A atividade de produzir a própria existência por meio do trabalho caracteriza e distingue o ser humano dos animais da mesma forma que o ato de educar; grosso modo, o trabalho e a educação são atividades indissolúveis ao homem. De acordo com Saviani (2007), há uma ligação histórico-ontológica entre educação e trabalho, uma vez que o ser do homem é um ser histórico e, portanto, do trabalho. O trabalho agregado à prática pedagógica trata-se de reconhecer e buscar compreender os processos em união à formação intelectual e produtiva, tal como afirma Saviani (2007): "na abordagem marxista o conceito de politecnia implica a união entre escola e trabalho ou, mais especificamente, entre instrução intelectual e trabalho produtivo".

Passado um século, o cenário educacional e os caminhos da transformação social se apresentam em contextos diversos daqueles de outrora, em 1917. No entanto, o modo de produção material da vida ainda se assenta na exploração da força de trabalho e extração de valor, moldando a reprodução da vida de forma cada vez mais débil e limitante, agredindo e ampliando o esvaziamento dos saberes e conhecimentos historicamente produzidos.

Com isso, pretende-se apresentar discussões que tornam a escola palco da luta de classes e de interesses do grande capital que, ao mesmo tempo que acumula e concentra para poucos, drena e consome as formas de humanização para muitos. Nessa perspectiva, o estudo se constitui como desdobramento de uma investigação teórica que busca apresentar os quadros que direcionaram o modelo de educação soviética, na qual Lenin defendia "o fim da escola" na velha sociedade russa, para refletir sobre os desafios de nosso tempo que apontam para "o fim da escola" que se universalizou na revolução burguesa.

\section{Na antessala da Revolução: uma retrospectiva necessária}

A Revolução Russa não pode ser entendida como um fato isolado, espontâneo ou sem qualquer raiz histórica. Ao contrário: os acontecimentos de outubro nos levam a episódios de revoltas populares tanto no continente europeu quanto na própria formação social russa que antecede a Revolução. Por essa razão, tratar 1917 e seus impactos sem antes apresentar o breve contexto que impulsionou tal evento pode ser fatal para a compreensão plena e vindoura. 
De 1613 a 1917, a Casa Romanov esteve a frente do que se chamou Império Russo. Vasto no domínio dos territórios, amplo na composição étnica e irregular na distribuição populacional, gradualmente o Império atenuou as contradições e criou as condições para a soberania do regime czarista. Enquanto na Europa ocidental as revoluções burguesas agitavam e se espalhavam pelo continente entre o final do XVIII e a primeira metade do século XIX, a Rússia ficava à margem dos ideais revolucionários. Após adentrar na Europa oriental em 1813 contra Napoleão, as ideias de abolição da servidão e adesão de uma Constituição inspiraram a Revolta Dezembrista, que teve como bandeiras a reforma agrária e adoção de uma monarquia constitucional.

A autocracia e a servidão apresentavam-se como entraves para o desenvolvimento capitalista em solos russos (SERGE, 2017, p. 40) e os efeitos escancaram-se na década de 1840. A parca produção agrícola míngua as exportações de trigo, a falta de mão-de-obra impede e tarda o avanço do desenvolvimento da manufatura. A derrota na Guerra da Criméia (1853-1856) demonstra a fraqueza econômica e política que sustentava o Império Russo, e levou Alexandre II a assinar em fevereiro de 1861 o ato legislativo de abolição da servidão. Para Alexandre II, "se a servidão tinha que ser abolida, é melhor que seja abolida a partir de cima, e não esperar que sua autolibertação parta de baixo" (WOOD, 1991, p. 24).

As reformas administrativas empreendidas pelo Império surtem grande efeito econômico; passados quinze anos, em 1876, a exportação de trigo russo para o mercado europeu aumentou em $140 \%$ (SERGE, 2017, p. 41). O fim da servidão mostrou-se positiva para as classes dominantes, no entanto, para os camponeses, o regime de servidão feudal converteu-se no regime de servidão econômica (SERGE, 2017 , p. 40). Na virada do século, com aumento populacional significativo, a industrialização russa salta de uma das mais atrasadas e menos desenvolvidas para o nível de potência mundial. Para o desenvolvimento do capitalismo, a escravidão ou servidão são formas primitivas de exploração - o trabalhador "livre" trabalha muito mais, por muito menos -, e a exploração laboral ganha um aliado imbatível: a fome. O controle de braços e mentes se mostrava mais eficaz que a violência aparente. Sob o pano de fundo industrial, o Império se colocava como uma moderna economia capitalista de sua época, tanto em aparência quanto em substância.

O desenvolvimento da força de trabalho russa sustentava economicamente uma classe média de industriais, banqueiros, financistas, negociantes e advogados. A juventude intelectual da pequenaburguesia, esquecida politicamente tanto pelo antigo regime quanto pelo capitalismo em ascensão, se torna um terreno fértil para ideias revolucionárias vindas do ocidente. Qualquer pensamento progressista vindo de camadas da burguesia - essa, afastada do poder político - tratava rapidamente de ser excluído do seio da sociedade em prol da continuidade de privilégios da elite. Militarmente, o Império contava com um brutal mecanismo de repressão a qualquer tentativa de revolta no tecido social. Concomitantemente, $80 \%$ da população ainda era composta por camponeses que viviam em comunas e vilas, sob condições de vida e trabalho que quase não tiveram grandes alterações desde o século XVIII (WOOD, 1991, p. 16). 
O agrário e o industrial, a servidão coexistindo com ideias progressistas vindas do ocidente: a camada mais alta - nobreza, corte e proprietários do grande latifundiário - gozava de prerrogativas exclusivas de uma sociedade feudal; as camadas médias estavam sedentas por poder político; o exército russo - um dos maiores do mundo -, equipado com as mais modernas técnicas bélicas, servia como braço armado do Império nas investidas no exterior e na manutenção da ordem e repressão interna; culturalmente, os russos exportavam as óperas de Tchaikovsky entoadas pelas companhias de ballet, o teatro de Tchekhov, os versos de Pushkin, a prosa de Gógol, os romances de Górki, a literatura existencialista de Tolstói e Dostoiévski, a exibição de filmes dos irmãos Lumière, a arquitetura bizantina da Catedral de São Basílio e os retratos de Rokotov; no campo, a servidão dá espaço ao endividamento e fome; na cidade, nasce o proletariado russo que, antes de tomar a Rússia pelas próprias mãos, urge pelo direito a uma vida digna.

\section{A educação política: do Império Russo ao cadafalso}

Nos escritos pré-1917, Lenin não se preocupa necessariamente com as concepções pedagógicas. Para Lenin, a educação tem uma intrínseca ligação com a política e economia, sendo, portanto, essencial que a base educacional esteja correlacionada com o compromisso da transformação política da sociedade, ou seja, a tomada de conhecimento das opressões e explorações do czarismo para poder então derrubá-lo. A educação nos escritos de Lenin desse período são guiadas por uma educação política. Em termos de alfabetização, em 1897, apenas $24 \%$ do total da população da Rússia czarista era alfabetizada (GRENOBLE, 2003, p. 46).

A frente do POSDR, Lenin toma a tarefa de educação política da massa explorada como um encargo do partido necessário não somente para conquistar melhores e mais dignas condições de trabalho, mas com a intenção final de derrubar o sistema que mantém essa forma de dominação. Escreve, assim, entre o final de 1901 e início de 1902, Que fazer?, profundamente influenciado pelo romance de nome homônimo, escrito por Tchernichevski em 1862. Se no último se lê “precisamente da mesma forma que se o desejo mais íntimo de cada pobre fosse cumprido, não restaria nenhum deles na terra” (1989, n.p., tradução nossa) ${ }^{3}$ e "mais cedo ou mais tarde, vamos organizar a vida de modo que não haja pobres" (1989, n.p., tradução nossa) ${ }^{4}$, em Lenin, adaptando o romance à proposição política, afirma:

\footnotetext{
A social-democracia dirige a luta da classe operária não só para obter condições vantajosas de venda da força de trabalho, mas para que seja destruído o regime social que obriga os não possuidores a venderem-se aos ricos. A social-democracia representa a classe operária não só na sua relação com um dado grupo de patrões, mas também nas suas relações com todas as classes da sociedade contemporânea, com o Estado como força política organizada. Compreende-se portanto que os sociais-democratas não só não possam circunscrever-se à luta económica, como nem sequer possam admitir que a organização das denúncias económicas constitua a sua atividade predominante. Devemos empreender activamente o trabalho de educação política da classe operária, de desenvolvimento da sua consciência política. (1982, p. 119, grifos nossos).
}

Nos grandes centros urbanos e industriais, o trabalhador russo não tinha direito a organização, associação ou proteção legal; em síntese, o proletariado russo não tinha sequer direito à vida, apenas o Germinal: Marxismo e Educação em Debate, Salvador, v. 12, n. 2, p. 359-371, out. 2020. ISSN: 2175-5604 
dever do trabalho. O proletariado russo, comprimido na indústria, somava mais de um milhão e seiscentos mil almas (SERGE, 2017, p. 56). O salário era o mais baixo de toda a Europa. O tempo dentro da fábrica era maior: os donos do maquinário roubavam de 10 a 14 horas do que resta de vida dessa massa, que pagava com a própria miséria a produção e desenvolvimento, mesmo de modo não intencional, do sistema que incessantemente drenava e ceifava o direito a existência irrestrita e liberdade plena.

A revolta popular era iminente. Em janeiro de 1905, o proletariado de São Petersburgo marchou rumo ao Palácio de Inverno reivindicando diminuição na jornada de trabalho para oito horas, direitos dos operários e uma constituição com maior atribuição aos ministros, liberdades democráticas e divisão entre Igreja e Estado (SERGE, 2017, p. 57). A autocracia respondia com emboscadas e tiros. O czar assistia do Palácio de Inverno o covarde massacre do povo. O Domingo Sangrento, escrito com sangue e repressão, surte efeito contrário e a manifestação aderiu caráter de greve geral. Nos dias que seguiram, 122 cidades e 10 linhas de rede ferroviária em toda a Rússia adotaram a greve (SERGE, 2017, p. 57). Lenin, três dias depois, escreve em O começo da Revolução na Rússia:

A classe operária recebeu uma grande lição de guerra civil; a educacão revolucionária do proletariado avancou num dia como não poderia avancar em meses e anos de vida cinzenta, enfadonba e oprimida. A palavra de ordem do heróico proletariado de Petersburgo «morte ou liberdade!» ecoa agora em toda a Rússia. Os acontecimentos desenrolam-se com uma rapidez surpreendente. A greve geral em Petersburgo cresce. Toda a vida industrial, social e política está paralisada. (1982, p. 377, grifos nossos).

O czarismo caminhava para a autodestruição. Como último recurso, Nicolau II assinou, relutante, o Manifesto de Outubro, que previa a criação da Duma Estatal do Império Russo - uma assembleia legislativa que poderia ser desmanchada pelo czar. Em contrapartida, algumas das liberdades democráticas foram conquistadas e a imprensa revolucionária surgiu como canal de divulgação e agitação política. Ainda em outubro, o Soviete dos Operários de Petersburgo é criado, atuando como um conselho independente da Duma, formado por um deputado para cada quinhentos operários (SERGE, 2017, p. 60).

Mesmo derrotado, o movimento de 1905 abriu caminho para a organização política enquanto classe. Os representantes dos bolchevique dividiam a atuação entre a legalidade permitida pela Duma do Império e a organização política dos trabalhadores nos conselhos operários. O trabalho para a educação política ganhava novos canais e meios de difusão. Em As três fontes e as três partes constitutivas do marxismo, publicado na Revista Prosvechtchénie (Educação), em março de 1913, Lenin assinala que os homens não podem ser vítimas políticas ingênuas, mas que continuarão a sê-lo enquanto não apreendem os interesses de uma ou de outra classe, advertindo que os partidários das reformas serão enganados pelos defensores do velho, mas que o velho se mantém pela força das classes dominantes. Com isso, postula "que para vencer a resistência dessas classes só há um meio: encontrar na própria sociedade que nos rodeia, educar e organizar para a luta, os elementos que possam - e, pela sua situação social, devam - formar a força capaz de varrer o velho e criar o novo" (LENIN, 1982, p. 38-39, grifos no original). A entrada dos russos na Primeira Guerra Mundial, em 1914, evidenciava motivos políticos e imperialistas.

Lenin e os bolcheviques acreditavam que a guerra poderia gerar conflitos e contradições que levariam a indignação e convulsão interna: a guerra mundial abriria caminho para colapso e guerra civil. A

Germinal: Marxismo e Educação em Debate, Salvador, v. 12, n. 2, p. 359-371, out. 2020. ISSN: 2175-5604 364


opinião pública com as seguidas baixas e reveses de guerra deram base concreta para a análise de Lenin. Os exércitos adversários adentraram às fronteiras russas e aos poucos grupos de soldados russos deserdaram e rebelaram-se contra os comandantes militares do Império. A imprensa revolucionária sofreu censuras, com jornais fechados e redatores presos e exilados. Os panfletos bolcheviques chegaram aos fronts de modo clandestino, convocando os combatentes a retirarem-se da guerra imperialista e tomarem as ruas na greve geral.

O Império cometera um drástico erro que custou séculos de dominação: enviou aos fronts operários e camponeses equipados com armas. A vida de constante fome e intermitente exploração, a morte de milhões de malfadados, crises econômicas e políticas, e principalmente a possibilidade de manejar armas de fogo converteram pobres trabalhadores em revolucionários. A população constantemente entrava em conflito com as autoridades; greves, choques violentos com a polícia e motins são organizados no começo de 1917. Entre fevereiro e março, as ruas são tomadas por milhares de almas russas, encoleiradas, famintas e sedentas pelo direito à existência. A Duma teve os trabalhos suspensos; o czar abdicou e surgiu o primeiro governo provisório, com Kerensky como primeiro-ministro; nascia o Soviete dos Deputados dos Trabalhadores e dos Soldados de Petrogrado. Lenin defende nas Teses de Abril, o trabalho de conscientização política que o partido devia incumbir em relação as massas. Na visão de Lenin, educar significa necessariamente contribuir para a transformação social. Sob esse contexto de guerras externas e agitações internas, o processo envolvido na educação política exprimiria, por consequência, a preparação das massas para o processo revolucionário futuro. $\mathrm{O}$ poder do Estado devia emanar da organização das massas oprimidas e exploradas em torno do Soviete e dos deputados operários. No entanto, na composição do governo provisório, a velha aristocracia e camadas não-radicais teve seus representantes entre os ministérios.

Em julho, os bolcheviques tomaram as ruas exigindo a queda do governo provisório e como represália, foram perseguidos e exilados; Trotsky volta do exilio e preside o Soviete de Petrogrado, mesma posição que exercera doze anos antes, em 1905; o governo provisório é derrubado; do exílio, Lenin trabalha na obra $\mathbf{O}$ Estado e a Revolução, e versa sobre a natureza que o Estado operário devia assumir após a Revolução.

Em setembro de 1917, mais uma vez, Lenin ressalta em Sobre os Compromissos as tarefas de um partido genuiramente revolucionário em não proclamar impossível a renúncia a qualquer compromisso, "mas em saber permanecer fiel, através de todos os compromissos, na medida em que eles são inevitáveis, aos seus princípios, à sua classe, à sua missão revolucionária, à sua tarefa de preparação da revolução e de educaşão das massas do povo para a vitória da revolução." (1988, p. 155, grifos nossos). Em 10 de outubro, Lenin volta a Petrogrado, participa da reunião do Comitê Central do Partido Bolchevique, argumenta pela necessidade de defender uma insurreição armada e vence; o Comitê Militar Revolucionário é criado e Trotsky é nomeado como líder desse órgão; em 24 de outubro, os bolcheviques assumem o controle das estações ferroviárias e das pontes, as agências de telégrafo e do correio (WOOD, 1991, p. 68); na noite do dia 24 e nas horas iniciais do dia 25 de outubro, os revolucionários infiltram no Palácio de Inverno com 
apoio de soldados e marinheiros, prendendo os membros do governo provisório; Kerensky, já tinha fugido para os Estados Unidos com apoio da embaixada estadunidense; o governo é derrubado. Pela primeira vez na história, os trabalhadores tomam o Estado. Uma nova era nasce, os trabalhadores de Petrogrado e de toda a Rússia carimbam o passaporte da história.

\section{A pedagogia socialista e o "fim da escola"}

Após 1917, Lenin dedicou-se ainda mais na produção de textos e brochuras a fim de orientar a nova sociedade originária do triunfo revolucionário. Mais do que nunca, a economia, a política e a educação precisariam estar alinhadas nas medidas do Estado dos sovietes. Havia defasagem tanto na qualificação quanto na própria existência de mão-de-obra. Os desafios da educação nos primeiros anos de República Soviética era o de superar o analfabetismo e o modo de produção alienante. Do grande número de escritos, discursos e relatórios produzidos nos anos iniciais pós-1917, destaca-se o Programa do PCR(b) de 1919, escrito a partir dos debates do VIII Congresso do PCR 5 , realizados entre 18 e 23 de janeiro. No que se refere à educação, o Programa destacava:

No campo da instrução pública, o PCR se dá como tarefa concluir a obra iniciada pela revolução de Outubro de 1917 - transformar a escola de um instrumento de dominação de classe nas mãos da burguesia em instrumento de destruição dessa dominação, assim como liquidar inteiramente a divisão da sociedade em classes (OYAMA, 2014, p. 147 apud DIETRICH, 1973, p.214-215, grifos nossos).

Assim, no que se refere à nova sociedade, o Programa postulava a transição para uma nova escola e decreta o "fim da escola" do antigo regime: uma escola que, nas considerações de Pistrak (2018), se caracterizava como livresca, individualista e pautada na tradição da "velha escola", representada pelo modelo educacional de uma elite dirigente. A transformação do Programa organizava um novo modelo de organização social sem classes:

O fundamento de todo o plano educacional da Revolução Russa era criar uma nova escola, com a finalidade de preparar um novo homem e uma nova mulher, com vistas a viver em uma sociedade sem classes. Uma das arquitetas desta concepção, H. K. Krupskaya, no prefácio do livro Escola-Comuna dirá: "A maioria [dos pedagogos da revolução] sabia apenas uma coisa: que a nova escola não deveria parecer-se com a antiga". (FREITAS, 2018, p. 14, grifos no original).

Com essa contribuição, fica evidente que o Programa colocava novas tarefas para a educação, inaugurando um período de transição com vistas a extinguir as classes sociais. A instrução que se postulava no Programa era: "gratuita e obrigatória, geral e politécnica (ensino da teoria e da prática dos principais ramos da produção), para as crianças de ambos os sexos até os 16 anos" (OYAMA, 2014, p. 147 apud DIETRICH, 1973, p.214-215). Há um incontestável esforço em romper com o fim da escola "livresca", apontando uma formação geral e politécnica, que buscasse fundir a educação intelectual e a educação de caráter científico voltada para um novo modelo de produção da vida. Nesse sentido, os fundamentos dessa "nova escola", buscavam: 
Realizar totalmente os princípios da escola única do trabalbo, liberando o ensino da língua materna; o ensino deve ser dado igualmente às crianças de ambos os sexos; é preciso criar uma escola absolutamente laica, ou seja, livre de toda influência religiosa, onde ocorra uma ligação estreita entre ensino e trabalho social produtivo e que garanta a marca da universalidade aos membros da sociedade comunista. (OYAMA, 2014, p. 147 apud DIETRICH, 1973, p.214-215, grifos nossos).

Diferente da "velha escola", que tinha seu programa focado na formação para trabalhadores com instrução dirigida à execução de tarefas manuais e industriais, ou seja, cindida da formação intelectual que outrora era privilégio exclusivo das camadas dirigentes, a escola do período de transição se dirigia "à preparação para a participação ativa da vida coletiva, em que já não fazia sentido a divisão entre trabalhadores que pensam e trabalhadores que executam - sendo necessária uma formação teórica e prática multilateral de todos os produtores da vida” (FREITAS; CALDART, 2018, p. 15).

Além de postular o "fim da escola" baseada na divisão social de classes, o Programa sinalizava para um projeto de sociedade que buscasse facilitar as condições de emancipação da mulher, ainda que naquele momento as medidas se restringissem apenas à preocupação com a instrução dos filhos, visto que o PCR reclamava por "uma rede de instituições pré-escolares: creches, jardins de infância, abrigos para crianças que aperfeiçoem a educação social e facilitem a emancipação da mulher" (OYAMA, 2014, p. 147 apud DIETRICH, 1973, p.214-215). Assim, constata-se uma preocupação com a construção de creches e escolas infantis para abrigar os filhos daquelas que já são mães, por meio de um projeto de educação que transmitia a responsabilidade de formação da família para a coletividade centralizada no Estado. Nota-se, igualmente, uma política sem distinção de gênero, visto que o Programa garantia o acesso à educação a ambos os sexos desde a mais tenra idade.

É oportuno destacar a dimensão de uma instrução intelectual e de formação geral por meio de um programa que valorizava o conhecimento científico, artístico e cultural para os cidadãos da nova sociedade que se projetava. Isso pode ser constatado neste fragmento:

\begin{abstract}
Abrir os anfiteatros das universidades a todos aqueles que têm o desejo de aprender qualquer coisa, e em primeiro lugar os trabalhadores, permitindo a todos que têm capacidade o acesso ao ensino universitário. Abolir todas as barreiras artificiais entre as novas forças científicas e a cátedra; assegurar a manutenção material àqueles que estudam para dar aos proletários e aos membros do campesinato a possibilidade real de frequentar a universidade. (OYAMA, 2014, p. 147 apud DIETRICH, 1973, p.214-215).
\end{abstract}

Denota-se a "velha escola" como uma organização que compreendia a educação básica como etapa final de formação centrada no trabalho, sugerindo que a transição para a formação superior se restringia apenas ao aperfeiçoamento técnico dos trabalhadores, portanto, com formação única e exclusivamente voltada para a execução da produção do sistema fabril. Em contrapartida, o fragmento demonstra as contribuições do Programa para a construção de uma pedagogia socialista, pela garantia do acesso ao conhecimento que antes era privilégio restrito da elite dirigente; há, portanto, a possibilidade de romper com as barreiras que cerceavam o acesso concreto e material dos trabalhadores e do campesinato à formação superior. É neste sentido que se postulava o "fim da escola", organizada para impedir o acesso ao conhecimento científico e filosófico de base humanista à classe trabalhadora. 
O Programa também se ocupava em quebrar as barreiras que até então impediam o acesso as obras artísticas, tidas como propriedade privada às custas da exploração do trabalho:

Do mesmo modo, devem ser acessíveis aos trabalhadores todos os tesouros artísticos que foram criados graças à exploração do seu trabalho, e se encontravam até o presente momento à disposição exclusiva dos exploradores. (OYAMA, 2014, p. 147 apud DIETRICH, 1973, p.214-215, grifos nossos).

Com isso, constata-se que as resoluções do Programa foram responsáveis por estabelecer diretrizes educacionais para os anos iniciais da construção da sociedade socialista na Rússia. Em síntese: nota-se uma preocupação com o estabelecimento da instrução pública universal e obrigatória; com a extinção de uma organização escolar pautada na divisão social de classes, possibilitando o acesso ao conhecimento teórico e prático de formação geral, intelectual e técnica; o duplo rompimento com o ensino pautado na ideologia cristã e burguesa das classes dominantes; possibilidade e condição material de acesso aos cursos de formação superior que não fossem voltados apenas para a execução de trabalho técnicos, com a abertura das universidades para os trabalhadores; e socialização do conhecimento científico, filosófico e artístico acumulado e construído a partir da exploração do trabalho, mas agora sem restrição privada de acesso pelo gênero humano.

As resoluções do Programa trazem contribuições de Lenin para a instauração de uma educação que estivesse a serviço da edificação do socialismo, postulando princípios e fundamentos para a construção de uma pedagogia socialista. "O fim da escola" levado a cabo no calor do momento da revolução dos sovietes significou a possibilidade de preservar o que há de mais importante da escola que se universalizou no ápice da revolução burguesa: seu caráter público e laico, em especial a possibilidade de acesso ao conhecimento historicamente acumulado pela cultura humana, porém, sem a divisão social de classes centrada na propriedade privada.

\section{Hoje, "o fim da escola" no capitalismo}

Vimos, de acordo com as contribuições de Lenin, que os "partidários de reformas e melhoramentos ver-se-ão sempre enganados pelos defensores do velho, enquanto não compreenderem que toda a instituição velha, por mais bárbara e apodrecida que pareça, se mantém pela força de umas ou de outras classes dominantes" (LENIN, 1982, p. 38-39). Na Rússia, o contexto pós-revolução demonstrou, por meio de um processo permeado de contradições, que a transição para uma sociedade em que a educação não seja terreno de disputas em torno da luta de classes, adquiriu possibilidades concretas de efetivação de uma pedagogia socialista que postulava "o fim da escola" organizada sob um modo de produção excludente, desigual, explorador e alienante.

Entretanto, a luta e a organização para "formar a força capaz de varrer o velho e criar o novo" (LENIN, 1982, p. 38-39), não se internacionalizou como programa do socialismo existente na União Soviética. Se por um lado as contribuições de Lenin galgaram êxitos em promover "o fim da escola" como 
projeto de uma educação socialista, no outro, o capitalismo sequer preservou as conquistas da classe que outrora fora revolucionária na França.

No que se refere ao conhecimento filosófico, cultural e artístico, Lukács (2010) destaca as consequências das Revoluções de 1848 na deterioração da ideologia burguesa, que outrora despontava como classe revolucionária. O filósofo analisa a crise espiritual burguesa, na medida em que o conhecimento, com raras exceções, foi se adequando às circunstâncias históricas do modo de produção capitalista, mas na forma apologética de negação das contradições da vida real, passando a se assegurar desse imperativo para se manter $o$ e no poder material e espiritual.

As últimas décadas do século XX imprimem, ainda que não exclusivamente, profundas mudanças nos diversos campos que abarcam a vida social, política, cultural e econômica das formações sociais. O projeto da globalização surge como uma tarefa essencialmente política que tem como objetivo resgatar o primado do capitalismo sobre a economia, a política e a cultura, que foram profundamente afetadas e reconfiguradas no período pós-Segunda Guerra Mundial, no advento do Estado de bem-estar social (1945-1975).

O fenômeno que acompanha a globalização, o capitalismo financeiro, de acordo Gallino (2011) é um longo processo que se intensifica após a dissolução da União Soviética e, sincronicamente possui uma ordem histórica que levou, após sucessivas reformas e políticas de Estado, um novo cenário de luta de classes. Essa sequência de reformas pelo alto apontou, entre outras, para a contenção do salário real dos trabalhadores e a supressão das conquistas e direitos sociais e econômicos presentes no Estado social, o diminuindo e paulatinamente esvaziando-o, ao mesmo tempo que formou a classe capitalista transnacional e tornou o mercado mundial, acelerando e intensificando as trocas econômicas.

No campo da educação, se no século XX houve alguns avanços relativos em relação à universalização da escola pública no centro do capitalismo pela socialização do conhecimento apologético, na periferia do sistema adentramos ao século XXI sem sequer garantir seus princípios básicos. A escola de nosso tempo é organizada pelos oligopólios capitalistas que lançam mão de programas e projetos relacionados à educação por meio dos think tanks, atuando a partir de fundações, institutos e organizações com o propósito de disseminar toda a ideologia que a sustenta. Sob a fachada de empresa com responsabilidade social, os think tanks foram capazes de produzir figuras e intelectuais orgânicos aptos a advogar pelas mudanças educacionais necessárias para o padrão de reprodução da força de trabalho.

Acirrando a decadência ideológica, os conteúdos escolares e a escola pública gradativamente são abandonados e esvaziados, corroborando para que a escola pública, após constantes ataques e medidas temerárias, conheça "o seu fim" sob o capitalismo, pela não garantia de direito público que se conquistou na revolução burguesa: no neoliberalismo o Estado atua no sentido de assegurar, de todos os meios, o destino de sua privatização. 


\section{Conclusão}

Sob distintos cenários, Lenin atribui propósitos distintos a educação e ao trabalho educativo. No primeiro momento, às vésperas da Revolução, apoiada em nenhuma teoria pedagógica, a educação assume função de etapa preparatória para o triunfo vindouro e, portanto, a educação torna-se estritamente política; após a tomada do poder do Estado, os apontamentos de Marx a despeito da educação politécnica são retomados e rediscutidos por Lenin, tendo como objetivo associar o desenvolvimento das forças produtivas da nova sociedade com formas de trabalho não-alienado.

Contraditoriamente, ao se analisar a escola de nosso tempo na periferia do capitalismo dependente, sob as atuais circunstâncias de desenvolvimento do capitalismo financeiro e comparar com o modelo de educação soviética de Lenin, verifica-se que a escola desses modelos caminha para o fim: se no capitalismo a escola conhece seu fim por meio de contínuos ataques à forma e aos conteúdos escolares, no socialismo a escola marcha ao fim na medida que supera a alienação e exteriorização do trabalho, fazendo assim com que as classes subalternas - essas, com o poder do Estado - alcancem a emancipação e a justa humanização.

Revisitar a obra de Lenin, mesmo após quase um século de sua morte, é a grande tarefa daqueles que aspiram atuar para a transformação social ante a bandeira do marxismo. No entanto, os desafios e intempéries encontrados nessa trajetória exigem zelo e aplicação revolucionários. É preciso não se contentar apenas em localizar e reproduzir as conclusões de outrora para replica-las fielmente no tempo presente, mas de inspirar-se nessas conjecturas para construir o novo, que deve ser, tal qual o marxismo o é: crítico e autocrítico.

\section{Referências:}

FREITAS, L. C.; CALDART, R. S. Apresentação. In: PISTRAK. M. M. Fundamentos da escola do trabalho. São Paulo: Expressão Popular, 2018.

GALLINO, L. Finanzcapitalismo: La civiltà del denaro in crisi. Torino: Einaudi, 2011.

GRENOBLE, L. A. Language Policy in the Soviet Union. Dordrecht: Kluwer Academic Publishers, 2003.

LENIN, V. Obras escolhidas. São Paulo: Alfa-Ômega, 1982. (Volume 1).

LENIN, V. Obras escolhidas. São Paulo: Alfa-Ômega, 1988. (Volume 2).

LENIN, V. Obras escolhidas. São Paulo: Alfa-Ômega, 1980. (Volume 3).

LENIN, V. Teses de Abril. Manifesto Comunista e Teses de Abril. São Paulo: Boitempo Editorial, 2017.

LUKÁCS, G. Marxismo e teoria da literatura. São Paulo: Expressão Popular, 2010.

MARX, K. Instruções aos delegados do Conselho Central Provisório, AIT, 1868. Textos sobre educação e ensino. São Paulo: Moraes, 1983. 
MARX, K; ENGELS, F. O Capital de Marx. Obras escolhidas. São Paulo: Alfa-ômega, 1961. (Volume 2).

OYAMA, E. R. Lenin, Educação e Revolução. Jundiaí: Paco Editorial, 2014.

PISTRAK. M. M. Fundamentos da escola do trabalho. 1. ed. São Paulo: Expressão Popular, 2018.

SAVIANI, D. Trabalho e educação: fundamentos ontológicos e históricos. Revista Brasileira de Educação. v. 12 n. 34 jan./abr. 2007.

SERGE, V. O ano I da Revolução Russa. São Paulo: Boitempo, 2017.

WOOD, A. As origens da Revolução Russa: de 1861 a 1917. São Paulo: Ática, 1991.

\begin{abstract}
Notas
1 Graduando em Ciências Sociais pela Universidade Estadual Paulista Julio de Mesquita Filho. Professor no projeto Cursinho Unificado do Campus de Araraquara (CUCA). Membro do Grupo de Pesquisa Estudos Marxistas em Educação da FCL/Ar Unesp http://dgp.cnpq.br/dgp/espelhogrupo/4311. Lattes: http://lattes.cnpq.br/8408417269654549; ORCID: https://orcid.org/00000001-6540-1946. Email: vinicius.azevedo@unesp.br

2 Doutorado em Trabalho Docente e Educação Ambiental pelo Programa de Pós-Graduação em Educação para a Ciência (UNESP/Bauru/SP). Professor Assistente do Departamento de Educação e do Programa de Pós-Graduação em Educação Escolar, na UNESP Araraquara (SP). Membro do Grupo de Pesquisa Estudos Marxistas em Educação da FCL/Ar Unesp http://dgp.cnpq.br/dgp/espelhogrupo/4311. Lattes: http://lattes.cnpq.br/4949469318546934. ORCID: https://orcid.org/00000002-8210-1184. Email: lucas.andre@unesp.br

3 No original: "Imprecisely the same way that if the most intimate desire of every poor person were to be fulfilled, there would be none of them left on the earth".

4 No original: "Sooner or later we'll be able to organize life in such a way that there'll be no more poverty".

5 No mesmo congresso, o POSDR é renomeado para Partido Comunista Russo (PCR).
\end{abstract}

Recebido em: 01.09.2020

Aprovado em: 25.09.2020 